\title{
Profile: Gordon E. Pike
}

Gordon E. Pike, a long-time enthusiastic supporter of the Materials Research Society, leads the Society in 1986 as President. Pike holds a BS in physics from Carnegie-Mellon University and PhD in solid state physics from the University of Pittsburgh. He joined Sandia National Laboratories in 1969, where in 1985 he was promoted to supervisor of the Electrical Properties of Materials Division. Research activities in his division encompass polycrystalline semiconductors, thin film metallizations, and inorganic and organic dielectric materials. His principal experimental and theoretical research interests include electronic hopping transport in insulators, superconductivity, radiation effects in MOSFET transistors, percolative conduction and diffusion in heterogeneous materials, properties of cermet materials, and electronic properties of semiconductor grain boundaries, especially in silicon and ceramic $\mathrm{ZnO}$.

His involvement with the Society began in 1981 when he served as co-chair of the symposium on Grain Boundaries in Semiconductors held at the MRS Annual Meeting. In 1983 he served as Meeting Chair of the Annual Meeting, with Bill Appleton and Bernie Kear. The 1983 Meeting was marked by significant growth in both technical content and participation by an international scientific community. Without staff or conference management support, Pike was responsible for coordinating both the programming aspects of the Meeting,

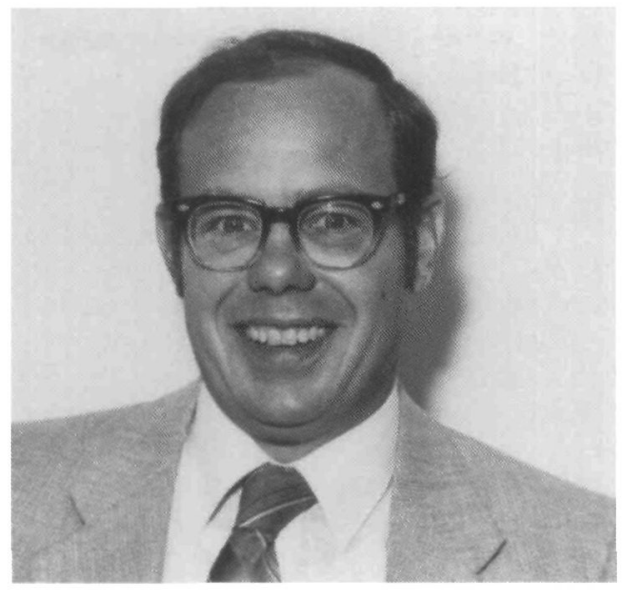

\section{MRS President}

as well as contracting and managing the conference facilities. In 1984, he served as chair of the Program Committee and as Meeting Chair for the Society's highly successful inaugural Spring Meeting, held in Albuquerque. He has also served on the Society's Publications, Finance, Corporate Participation, External Affairs, Awards, Nominations, and Long Range Planning Committees.

As First Vice President and PresidentElect in 1985, Pike supported the growth of the MRS Headquarters in Pittsburgh during its second year of operation. During this period, the Headquarters staff tripled in size, implemented a computer system for membership records and general Society management, and undertook a number of key new membership service activities. At the same time, Pike was instrumental in shaping the expansion of the MRS Short Course Program, which includes for 1986 many new course topics and more frequent and flexible schedules, as well as the new On-Site course program. He was also actively involved in establishing Journal of Materials Research, which begins publication in early 1986.

Pike is a member of the American Physical Society, serving four years in the APS Visiting Physicist Program, as well as a member of the American Ceramic Society and AAAS. His concern for strong intersociety communication in the United States and abroad has resulted in a number of cooperative efforts and has set a strong momentum for exchange and interaction during the coming year.

Emphasized 1984 MRS President Woody White, "Gordon Pike is one of the most dedicated, competent and well-organized individuals I have had the pleasure of working with. Under his direction, the Society is assured of continued growth, while maintaining as its primary goal its service to the world community of materials research professionals."

Pike outlines his plans for 1986 in an article in this issue.

\section{MRS Executive Committee}
G. E. Pike
Sandia National Laboratories
K. C. Taylor
GM Research Laboratories

B. R. Appleton

Oak Ridge National Laboratory

R. W. Balluffi

Massachusetts Institute of Technology

W. L. Brown

ATET Bell Laboratories

R. P. H. Chang

ATET Bell Laboratories

M. S. Dresselhaus

Massachusetts Institute of Technology
J. E. E. Baglin

IBM Watson Research Center

R. C. Ewing

University of New Mexico

C. W. Draper

ATET Technologies

\section{MRS Councillors}

J. C. C. Fan

MIT Lincoln Laboratory

L. C. Feldman

ATET Bell Laboratories

L. W. Hobbs

Massachusetts Institute of Technology

N. M. Johnson

Xerox PARC

J. Narayan

Microelectronics Center of North Carolina
J. B. Ballance Materials Research Society

E. N. Kaufmann Lawrence Livermore National Laboratory

R. M. Osgood, Jr. Columbia University

R. Roy Pennsylvania State University

F. Spaepen Harvard University

L. R. Testardi National Bureau of Standards

F. W. Young

Oak Ridge National Laboratory 